\section{Discussion}

The results clearly show that ergocryptine suppresses postpartum lactation. Our previous experience with ergocryptine in the treatment of non-puerperal galactorrhoea (Lutterbeck et al., 1971) also suggests a specific antiprolactin action. In the doses used the efficacy of ergocryptine and stilboestrol was similar. The only woman who received ergocryptine (Case 2) to experience acute mammary engorgement and exhibit definite congestion continued to suffer from galactorrhoea with amenorrhoea for five months after delivery. Shortly after readministering ergocryptine (1 $\mathrm{mg}$ thrice daily) to this patient galactorrhoea ceased and normal menstruation with ovulation started. This patient's response as well as that of others will be the subject of a separate report attempting to elucidate the mechanism of action of ergocryptine.

In several patients other than those in the trial ergocryptine was found to be effective not only when administered immediately post partum but also when lactation was established. In the latter situation oestrogens are much less effective, often failing or requiring much higher doses, which in turn may cause undesirable side effects. The above-mentioned dosages of ergocryptine were well tolerated and produced no side effects.

An exact dosage and duration of treatment schedule for ergocryptine is not yet available, but it seems that the schedule used in the trial will be very close to the most effective regimen. Of particular importance is the gradual lowering of the dose to avoid the rebound mammary engorgement which has been observed in several cases on discontinuing the higher doses.

The overall objective of this study was further to support the findings of various investigators in animals that ergocryptine interferes with pituitary prolactin (Flückiger and Wagner, 1968; Heuson et al., 1970; Yanai and Nagasawa, 1970b, 1971; Billeter and Flückiger, 1971; Cassell et al., 1971; Pasteels et al., 1971; Quadri and Meites, 1971; Stahelin et al., 1971; Hoekfelt and Fuxe, 1972; Schams et al., 1972). We think that our results, along with those obtained from our experience in treating nonpuerperal galactorrhoea, strongly indicate that ergocryptine may indeed interfere with pituitary prolactin. Studies involving prolactin blood levels in appropriate clinical conditions before and after ergocryptine administration are at present in progress.

Despite the possibility of an association between the use of oestrogen and the incidence of thromboembolism (Daniel et al., 1967, 1968a, 1968b; Jeffcoate et al., 1968), the evidence is by no means entirely conclusive (Gillibrand and Huntingford, 1968; Gunther and Kohorn, 1968; Llewellyn-Jones, 1968;
Drill, 1972; Drill and Calhoun, 1972). A much larger series of cases must be studied before any conclusions can be drawn on whether there is an increased incidence of thromboembolism in subjects treated with oestrogens.

This preliminary study, showing the ability of ergocryptine to suppress puerperal lactation, should encourage further investigation. Detailed hormonal evaluation of the pharmacology of ergocryptine in various clinical states will be needed to establish more specifically the mechanism of action. Whether ergocryptine is preferable to oestrogen therapy in the puerperium will depend on the results of substantial additional investigations, particularly the incidence of thromboembolism.

\section{References}

Billeter, E., and Flückiger, E. (1971). Experientia, 27, 464.

Cassell, E. F., Meites, J., and Welsch, C. W. (1971). Cancer Research, 31, 1051 .

Daniel, D. G., Campbell, H., and Turnbull, A. C. (1967). Lancet, 2, 287

Daniel, D. G., Bloom, A. L., Giddings, J. C., Campbell, H., and Turnbull, A. C. (1968a). British Medical fournal, 1, 801.

Daniel, D. G., Turnbull, A. C., Campbell, H., Bloom, A. L., and Giddings, J. C. (1968b). British Medical fournal, 4, 451.

Drill, V. A. (1972). Fournal of the American Medical Association, 219, 583.

Drill, V. A., and Calhoun, D. W. (1972). Fournal of the American Medical Association, 219, 593.

Flückiger, E., and Wagner, H. R. (1968). Experientia, 24, 1130.

Forsyth, I. A., Besser, G. M., Edwards, C. R. W., Francis, L., and Myres, R. P. (1971). British Medical fournal, 3, 225.

Frantz, A. G., and Kleinberg, D. L. (1970). Science, 170, 745.

Friesen, H., Guyda, H., and Hardy, I. (1970). Fournal of Clinical Endocrinology and Metabolism, 31, 611

Gillibrand, P. N., and Huntingford, P. J. (1968). British Medical fournal, 4, 769.

Gunther, M., and Kohorn, E. I. (1968). British Medical fournal, 4, 769.

Heuson, J. C., Waelbroeck-van Gaver, C., and Legros, N. (1970). European Fournal of Cancer, 6, 353.

Hoekfelt, T., and Fuxe, K. (1972). Neuroendocrinology, 9, 100.

Jeffcoate, T. N. A., Miller, J., Roos, R. F., and Tindall, V. R. (1968). British Medical Fournal, 4, 19.

Llewellyn-Jones, D. (1968). Btritish Medical fournal, 4, 387.

Lutterbeck, P. M., Pryor, J. S., Varga, L., and Wenner, R. (1971). British Medical fournal, 3, 228 .

Pasteels, J. L., Danguy, A., Frérotte, M., and Ectors, F. (1971). Annales d'Endocrinologie, 32, 188.

Quadri, S. K., and Meites, J. (1971). Proceedings of the Society for Experimental Biology and Medicine, 138, 999.

Schams, D., Reinhardt, V., and Karg, H. (1972.) Acta Endocrinologica (Kobenhavn), Suppl. No. 159, p. 39.

Stähelin, H., Burckhardt-Vischer, B., and Flückiger, E. (1971). Experientia, $27,915$.

Yanai, R., and Nagasawa, H. (1970a). Experientia, 26, 649.

Yanai, R., and Nagasawa, H. (1970b). National Cancer Institute Monographs, 45,1105

Yanai, R., and Nagasawa, H. (1971). Experientia, 27, 934.

\title{
Clinical Screening of Epipodophyllotoxin VM26 in Malignant Lymphomas and Solid Tumours
}

\section{European Organization for Research on the Treatment of Cancer, Co-operative Group for Leukaemias and Haematosarcomas*}

British Medical fournal, 1972, 2, 744-748

\section{Summary}

Epipodophyllotoxin (VM 26; 4'-demethyl-epipodophyllotoxin- $\beta$-D-thenylidene glucoside) has been proved, in clinical screening, to be able to induce apparently com-

\footnotetext{
*Active members participating in the trial: A. R. Broc, G. Brulé, F. Cabanne, P. Cappelaere, A. Cattan, C. Cauchie, J. Chauvergne, B. Clavel, P. F Combes, J. Coudeyras, J. Gary-Bobo, O. Godin, J. Guerrin, M. Hayat, F. de Vassal, C. Jeanne, R. Keiling, T. J. Kuipers, G. Mathe, F. MayLevin, M. Namer, J. P. Pollet, S. Schraub, J. M. Spitalier, J. Tardiveau, J. P. Wolff.
}

plete remissions and pronounced though incomplete regressions in Hodgkin's disease, reticulosarcoma, and bladder cancer, as well as incomplete regressions in lymphosarcoma. Apparently complete regressions of malignant pleural effusions have been obtained after giving this drug systemically. It has a notable toxic action on the bone marrow.

\section{Introduction}

Epipodophyllotoxin (VM 26; 4'-demethyl-epipodophyllotoxin$\beta$-D-thenylidene glucoside) (see Formula) is a semisynthetic 
derivative of podophyllotoxin. This drug has a cytostatic action in vitro that prevents the cells entering mitosis or destroys them in the premitotic phase (Stähelin, 1970). The drug acts in vivo on L1210 leukaemia, Ehrlich ascites tumour, and Walker 256 tumour, the growth of which is inhibited to nearly $100 \%$ (Stähelin, 1970).

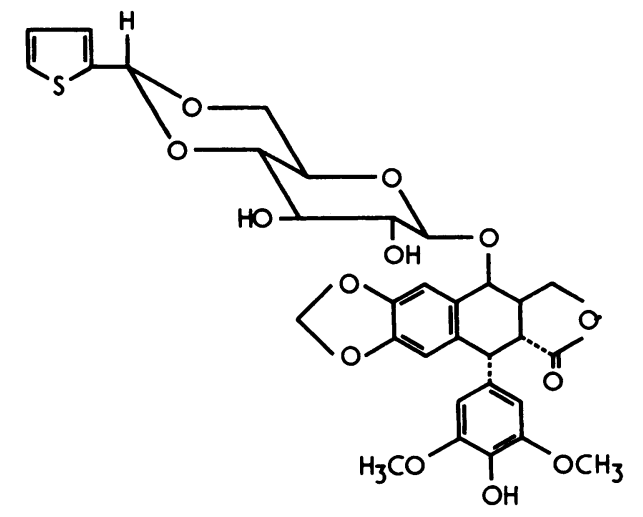

4-demethyl-epipodophyllotoxin- $\beta$-D-thenylidene glucoside

We have carried out a clinical trial to study the activity of epipodophyllotoxin on human tumours. The trial was not comparative, being designed only to find out whether favourable effects could be observed after giving the drug to patients with growing tumours and to test the sensitivity of tumours of various histological types to this drug. Because the action of this drug is similar to vincristine and vinblastine, patients with Hodgkin's disease, lymphosarcoma, and reticulosarcoma were specially included in the trial.

\section{Patients and Methods}

Patients.-In the trial 185 patients were treated with epipodophyllotoxin. There were 22 with Hodgkin's disease, 25 with reticulosarcoma (poorly differentiated or differentiated), 19 with poorly differentiated lymphosarcoma, and 119 with various solid metastatic tumours. Their distribution according to diagnosis, age, and sex is given in Table $I$.

Drug Administration.-In 37 patients a daily dose of 30 $\mathrm{mg} / \mathrm{m}^{2} /$ day by intravenous perfusion over one hour was given for 10 to 20 days. In $29(78 \%)$ of these a prolonged and severe bone marrow depression occurred and necessitated the stopping of the treatment. There were no fatalities. Thereafter epipodophyllotoxin was given by intravenous perfusion at a dose of $30 \mathrm{mg} / \mathrm{m}^{2} /$ day for five days. Courses of treatment were repeated at intervals of 10 to 15 days. The number of courses varied between one and six.
Evaluation of Antitumour Effect.-The results were evaluated as follows: apparently complete regression defined by the complete disappearance of all signs and symptoms of the disease and return to normal values of the biological determinations; incomplete regression when there was a significant decrease of all or several pathological manifestations (including necessarily a marked decrease of tumour masses), without any signs of progression during a period of at least one month; partial failure when the overall result of the treatment was considered as a failure, although one or several of the pathological signs had regressed; and total failure when no regression was observed.

\section{Results}

\section{SIDE EFFECTS}

The signs of intolerance to epipodophyllotoxin are summarized in Table II. The toxic effects are mainly on haemopoiesis: isolated neutropenia (less than 2,000 leucocytes $/ \mathrm{mm}^{3}$ ) occurred in 35 patients, isolated thrombocytopenia (less than 100,000 platelets $/ \mathrm{mm}^{3}$ ) in 13 patients, and pancytopenia (associated leucopenia and thrombocytopenia) in 17 patients. Depression of bone marrow activity occurred more often in patients who had been given $50 \mathrm{mg} /$ day for 10 or more days. In 14 patients the marrow depression was reversible, in three it led to fatal haemorrhage and/or leucopenia and septicaemia; these three fatalities were in patients who had received extensive irradiation and prolonged chemotherapy before epipodophyllotoxin. Alopecia was observed in 16 patients and gastrointestinal symptoms (nausea, vomiting, and diarrhoea) in 17. Three patients had stomatitis.

Three patients with Hodgkin's disease developed herpes zoster, and one developed chicken-pox during their treatment with epipodophyllotoxin.

A study of the immunological responses was made systematically each week in certain patients by using the battery of tests listed in Table III. This study indicated that epipodophyllotoxin, used according to this dose schedule, caused no important immunosuppressive effect.

\section{ANTITUMOUR EFFECT}

Hodgkin's Disease.-The overall results are given in Table IV. Out of 22 patients treated there was one apparently complete remission, five incomplete remissions, six partial failures, and 10 total failures. The complete remission was obtained in a 58 year-old woman with stage IIIA disease, after four courses of treatment. The remission was short, lasting only one month (Fig. 1). Two patients presenting with pleural effusions were

TABLE I-Details of Patients in the Trial

\begin{tabular}{|c|c|c|c|c|c|c|c|c|c|c|c|}
\hline \multicolumn{8}{|c|}{ Diagnosis } & \multirow{2}{*}{$\begin{array}{c}\text { No. of Cases } \\
22 \\
25 \\
19 \\
119 \\
\end{array}$} & \multirow{2}{*}{$\begin{array}{c}\text { Age } \\
29-50 \\
10-74 \\
12-74 \\
17-77\end{array}$} & \multirow{2}{*}{$\begin{array}{c}\text { Females } \\
7 \\
10 \\
8 \\
59\end{array}$} & \multirow{2}{*}{$\begin{array}{c}\text { Males } \\
15 \\
15 \\
11 \\
60 \\
\end{array}$} \\
\hline $\begin{array}{l}\text { Hodgkin's disease } \\
\text { Reticulosarcoma } \\
\text { Lymphosarcoma } \\
\text { Solid tumours . . }\end{array}$ & $\begin{array}{l}\cdots \\
\cdots \\
\cdots\end{array}$ & $\begin{array}{l}. \\
\because \\
\cdots\end{array}$ & $\begin{array}{l}\because \\
\because \\
\therefore\end{array}$ & $\begin{array}{l}. \\
\because \\
\because\end{array}$ & $\begin{array}{l}\ddot{y} \\
\because \\
.\end{array}$ & $\begin{array}{l}\ldots \\
\cdots \\
\cdots\end{array}$ & $\begin{array}{l}\because \\
\therefore \\
\therefore\end{array}$ & & & & \\
\hline Total & .. & $\ldots$ & $\ldots$ & .. & .. & $\ldots$ & .. & 185 & & 84 & 101 \\
\hline
\end{tabular}

TABLE II-Summary of Toxic Effects of Epipodophyllotoxin

\begin{tabular}{|c|c|c|c|c|c|c|c|c|c|c|}
\hline \multicolumn{5}{|c|}{ Disease } & \multirow{2}{*}{$\begin{array}{c}\text { No. of Cases } \\
22 \\
25 \\
19 \\
119\end{array}$} & \multirow{2}{*}{$\begin{array}{c}\begin{array}{r}\text { Neutropenia } \\
<2,000 / \mathrm{mm}^{2}\end{array} \\
7 \\
6 \\
4 \\
18\end{array}$} & \multirow{2}{*}{$\begin{array}{c}\begin{array}{c}\text { Thrombocytopenia } \\
<100,000 / \mathrm{mm}^{2}\end{array} \\
3 \\
1 \\
2 \\
7\end{array}$} & \multirow{2}{*}{$\begin{array}{c}\text { Pancytopenia } \\
3 \\
5^{*} \\
3 \\
6 \dagger\end{array}$} & \multirow{2}{*}{$\begin{array}{c}\text { Gastrointestinal } \\
3 \\
1 \\
0 \\
13\end{array}$} & \multirow{2}{*}{$\begin{array}{c}\text { Alopecia } \\
5 \\
2 \\
1 \\
8\end{array}$} \\
\hline $\begin{array}{l}\text { Hodgkin's disease } \\
\text { Reticulosarcoma } \\
\text { Lymphosarcoma } \\
\text { Solid tumours }\end{array}$ & $\begin{array}{l}\cdots \\
\because \\
\cdots\end{array}$ & $\begin{array}{l}\ldots \\
\cdots \\
\cdots\end{array}$ & $\begin{array}{l}. \\
\because \\
\because\end{array}$ & $\begin{array}{l}\ldots \\
\ldots \\
\ldots\end{array}$ & & & & & & \\
\hline Total & .. & $\ldots$ &.. & $\ldots$ & 185 & 35 & 13 & 17 & 17 & 16 \\
\hline
\end{tabular}

* One case was fatal.

†Two cases were fatal. 
treated with epipodophyllotoxin; in one the effusion resolved without any additional local therapy.

Reticulosarcoma.-The overall results are given in Table V. Out of 25 patients treated, 13 had incomplete remissions (two of which were in leukaemic reticulosarcomas), six partial failures, and six total failures. Four of these patients had pleural effusions; in two of them the treatment produced a complete and
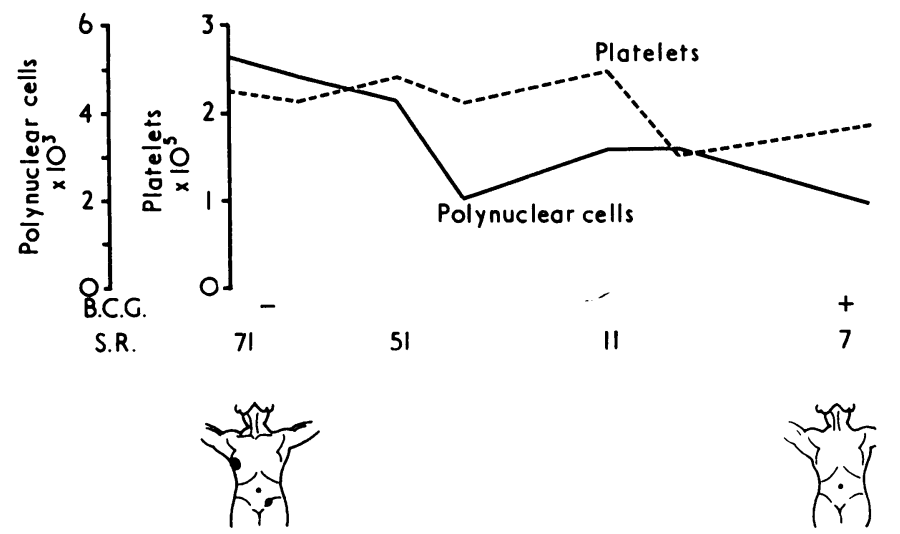

Epipodophyllotoxin

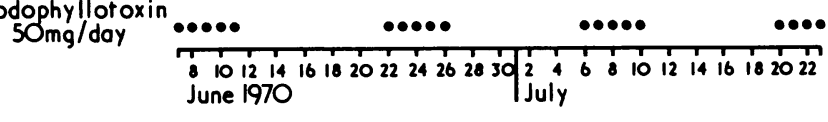

FIG. 1-Complete remission obtained in a woman aged 58 with Hodgkin's disease (type IIIA) after four courses of epipodophyllotoxin. (S.R. = sedimentation rate.) lasting resolution (Figs. 2 and 3). Among the responders, nine had no previous therapy, two were treated with radiation therapy alone, and two with radiation therapy and chemotherapy.

Lymphosarcoma.-The results are summarized in Table V. Out of 19 patients treated, six had incomplete remissions, six partial failures, and seven total failures. In three patients there were spectacular regressions of a pleural effusion (Fig. 4),

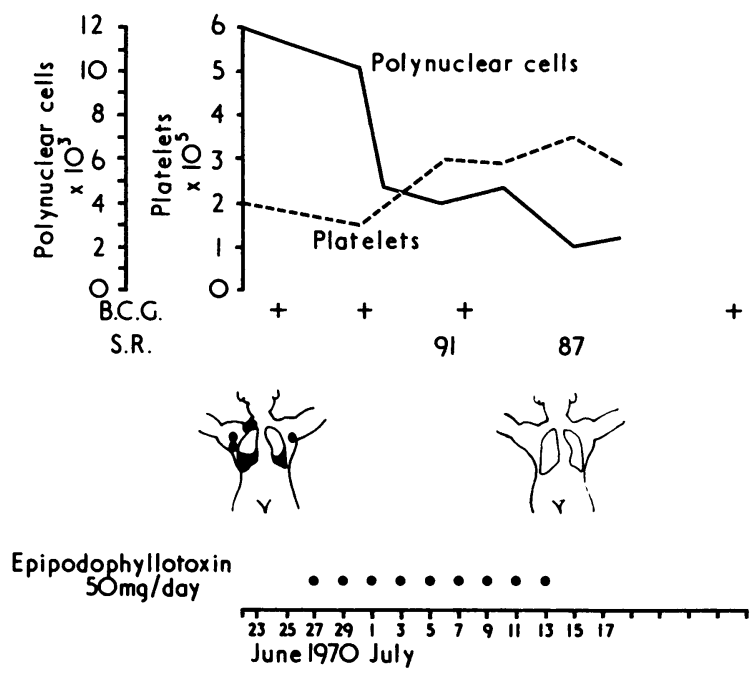

FIG. 2-Incomplete remission obtained in a 20 -year-old man with reticulosarcoma and bilateral pleural effusions.

TABLE III-Study of Immune Responses in Patients before and after Treatment with Epipodophyllotoxin

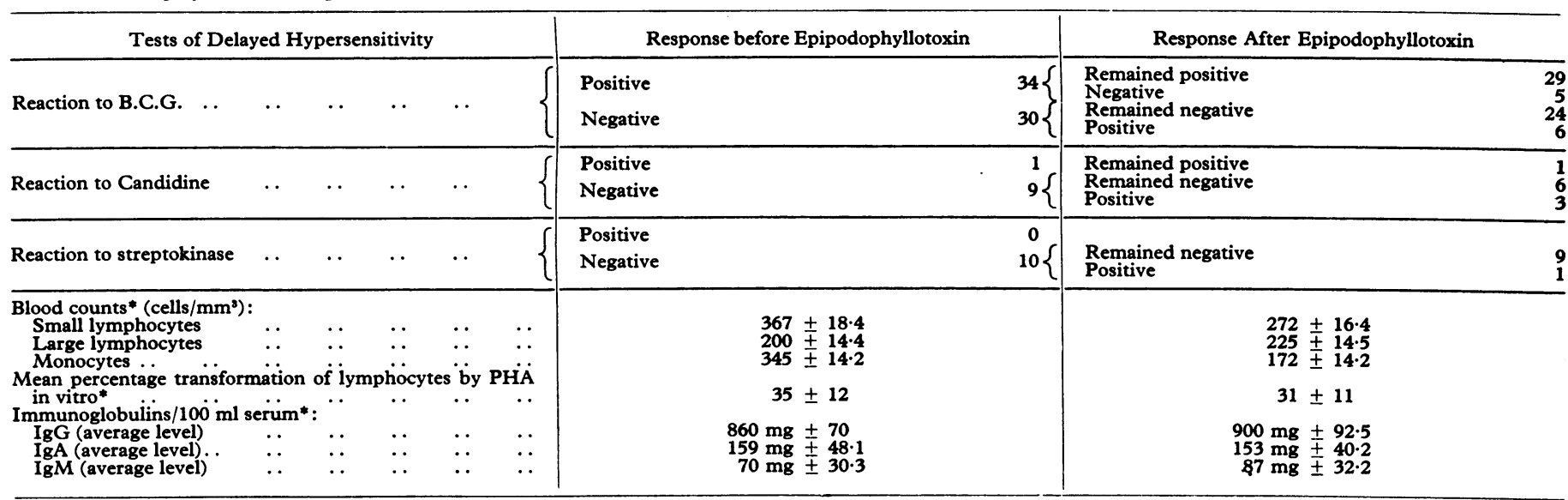

* Mean values from measurements on 12 patients.

TABLE IV-Results Obtained in Hodgkin's Disease by Treatment with Epipodophyllotoxin

\begin{tabular}{|c|c|c|c|c|c|c|c|c|c|c|c|}
\hline \multirow{2}{*}{\multicolumn{7}{|c|}{ Stage }} & \multirow{3}{*}{$\begin{array}{r}\text { No. of Cases } \\
5 \\
2 \\
4 \\
10 \\
1\end{array}$} & \multicolumn{2}{|c|}{ Remissions } & \multicolumn{2}{|c|}{ Failures } \\
\hline & & & & & & & & \multirow{2}{*}{$\frac{\text { Apparently Complete }}{1}$} & \multirow{2}{*}{$\begin{array}{c}\text { Incomplete } \\
2 \\
1 \\
2\end{array}$} & \multirow{2}{*}{$\begin{array}{c}\text { Partial } \\
1 \\
2 \\
3\end{array}$} & \multirow{2}{*}{$\begin{array}{c}\text { Total } \\
2 \\
2 \\
5 \\
1\end{array}$} \\
\hline 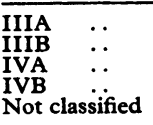 & $\begin{array}{l}\cdots \\
\cdots \\
\cdots\end{array}$ & $\begin{array}{l}\cdots \\
\cdots \\
\cdots \\
\cdots\end{array}$ & $\begin{array}{l}\ldots \\
\cdots \\
\cdots \\
\cdots\end{array}$ & $\begin{array}{l}. \\
\cdots \\
\cdots \\
\cdots\end{array}$ & $\begin{array}{l}\ldots \\
\cdots \\
\cdots \\
\cdots\end{array}$ & $\begin{array}{l}. \\
\because \\
\because \\
\therefore\end{array}$ & & & & & \\
\hline Total & $\ldots$ & $\ldots$ &. & $\ldots$ & . & .. & 22 & 1 & 5 & 6 & 10 \\
\hline
\end{tabular}

TABLE V-Results Obtained with Epipodophyllotoxin in Treatment of Reticulosarcoma and Lymphosarcoma

\begin{tabular}{|c|c|c|c|c|c|c|c|c|c|c|c|}
\hline \multirow{2}{*}{\multicolumn{7}{|c|}{ Disease }} & \multirow{3}{*}{$\begin{array}{r}\text { No. of Cases } \\
23 \\
2\end{array}$} & \multicolumn{2}{|c|}{ Remissions } & \multicolumn{2}{|c|}{ Failures } \\
\hline & & & & & & & & \multirow{2}{*}{$\begin{array}{c}\text { Apparently Complete } \\
- \\
\end{array}$} & \multirow{2}{*}{ 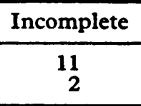 } & \multirow{2}{*}{$\frac{\text { Partial }}{6}$} & \multirow{2}{*}{$\frac{\text { Total }}{6}$} \\
\hline $\begin{array}{l}\text { Reticulos } \\
\text { Leukaem }\end{array}$ & $\begin{array}{l}\text { na } \\
\text { icul }\end{array}$ & rcoma & $\therefore$ & $\because$. & $\because$ & $\therefore$ & & & & & \\
\hline Total & .. & $\ldots$ & .. & .. &.. & . & 25 & - & 13 & 6 & 6 \\
\hline Lymphos & & $\ldots$ & $\ldots$ & .. &.. & .. & 19 & - & 6 & 6 & 7 \\
\hline
\end{tabular}



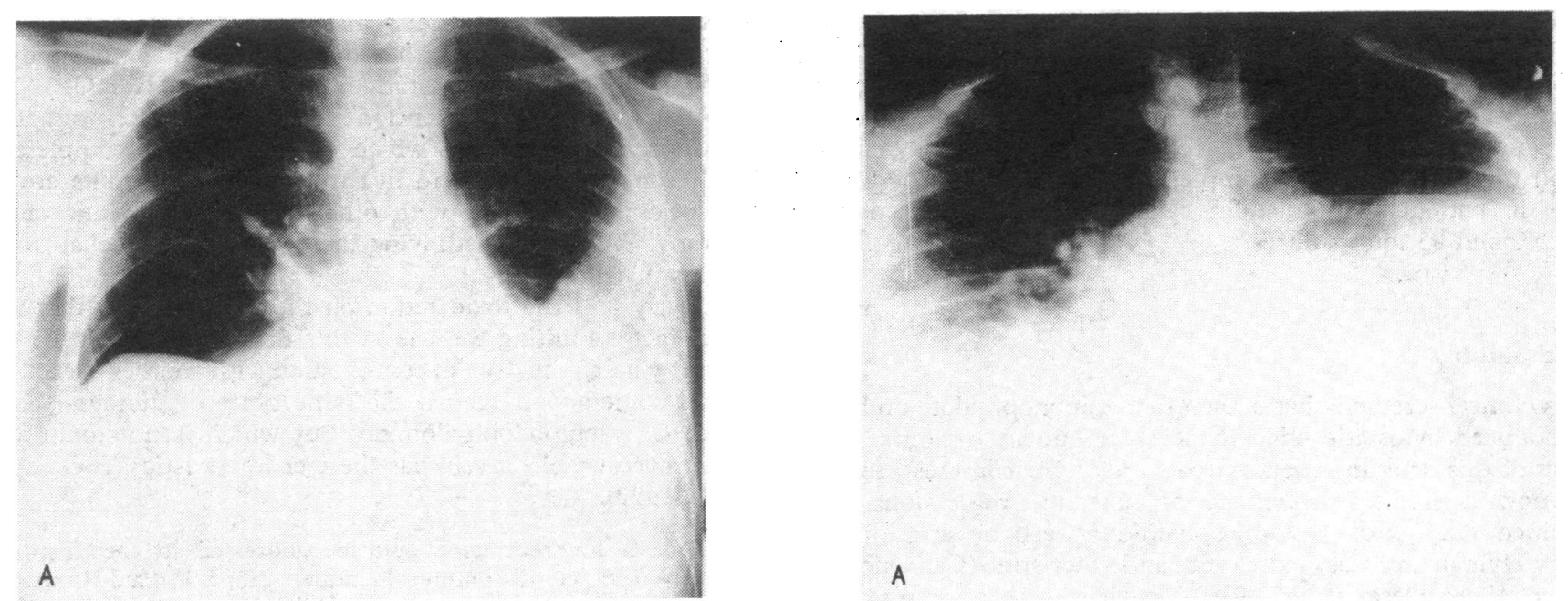

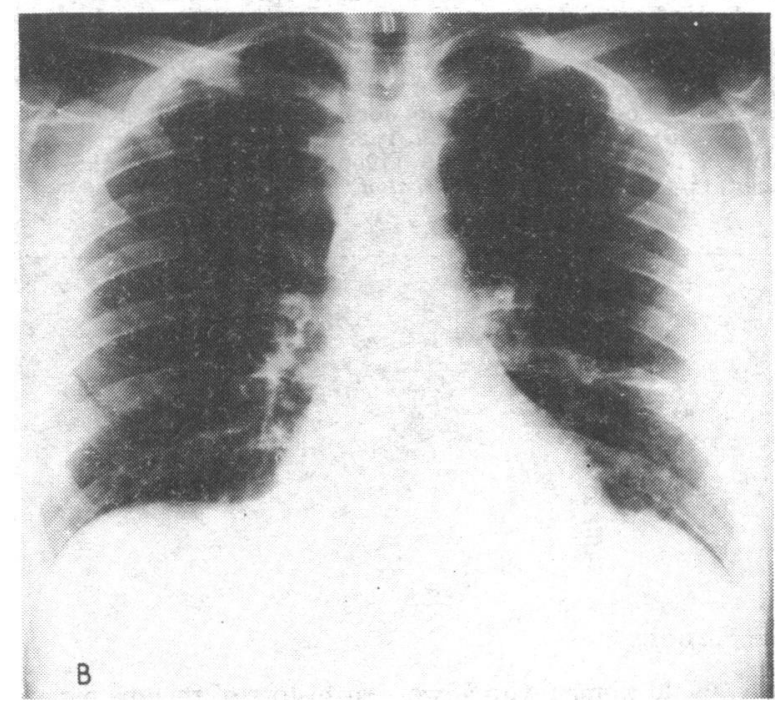

FIG. 3-Resolution of a left pleural effusion in a patient with reticulosarcoma after two courses of epipodophyllotoxin without any other local treatment. $\mathrm{A}$, before treatment. B, after treatment.

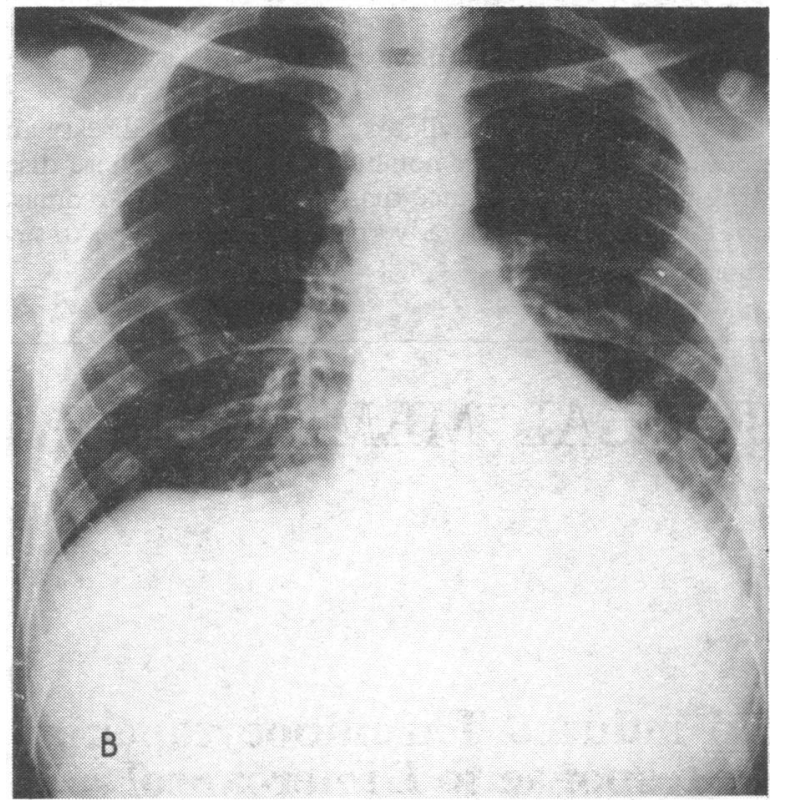

PIG. 4-Resolution of a bilateral effusion in a 22-year-old man with a poorly differentiated lymphosarcoma after treatment with epipodophyllotoxin. This regression was followed by a relapse a few days after stopping the treatment. A, before treatment. B, after treatment.

TABLE VI-Results Obtained with VM 26 in Treatment of Various Solid Tumours

\begin{tabular}{|c|c|c|c|c|c|c|c|c|c|c|c|}
\hline \multirow{2}{*}{\multicolumn{7}{|c|}{ Tumour Site or Type }} & \multirow{2}{*}{ No. of Cases } & \multicolumn{2}{|c|}{ Regressions } & \multicolumn{2}{|c|}{ Failures } \\
\hline & & & & & & & & Apparently Complete & Incomplete & Partial & Total \\
\hline $\begin{array}{l}\text { Head and neck } \\
\text { Lung ... } \\
\text { Oesophagus } \\
\text { Rectum } \\
\text { Kidney .. } \\
\text { Bladder } \\
\text { Prostate } \\
\text { Penis } \\
\text { Testicle . } \\
\text { Breast .. } \\
\text { Ovary .. } \\
\text { Cervix .. } \\
\text { Endometrium } \\
\text { Vagina and vulva } \\
\text { Retroperitoneal } \\
\text { Ewing s tumour } \\
\text { Osteosarcoma } \\
\text { Soft tissue sarco } \\
\text { Melanoma } \\
\text { Glioms .. } \\
\text { Astrocytoma } \\
\text { Unknown prima } \\
\end{array}$ & 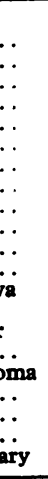 & $\begin{array}{l}\ldots \\
\because \\
\because \\
\because \\
\because \\
\because \\
\because \\
\because \\
\because \\
\because \\
\because \\
\because \\
\because \\
\because \\
\because \\
.\end{array}$ & 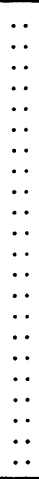 & 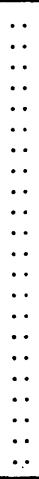 & 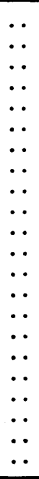 & 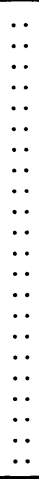 & $\begin{array}{r}16 \\
7 \\
12 \\
3 \\
5 \\
24 \\
1 \\
1 \\
1 \\
22 \\
1 \\
7 \\
2 \\
3 \\
2 \\
2 \\
2 \\
2 \\
3 \\
1 \\
1 \\
1 \\
\end{array}$ & 1 & 4 & $\begin{array}{l}5 \\
1 \\
2 \\
2 \\
4 \\
2 \\
1 \\
1 \\
1\end{array}$ & $\begin{array}{r}11 \\
7 \\
11 \\
1 \\
3 \\
15 \\
1 \\
1 \\
1 \\
18 \\
1 \\
6 \\
2 \\
3 \\
2 \\
2 \\
1 \\
1 \\
3 \\
1 \\
1 \\
1\end{array}$ \\
\hline 'Total & . & . & .. & .. & $\cdots$ & $\ldots$ & 119 & 1 & 6 & 19 & 93 \\
\hline
\end{tabular}


tumour mass, or enlarged nodes that had been increasing rapidly. The apparently complete remission was obtained after two courses of treatment.

Solid Tumours.-The overall results are summarized in Table VI. Out of 119 patients treated, one with bladder cancer had an apparently complete regression after a seven-day course of $50 \mathrm{mg} /$ day; six had incomplete regressions, four of which were in patients with bladder cancer; there were 19 partial failures and 93 total failures.

\section{Discussion}

This clinical screening has shown that epipodophyllotoxin has a pronounced cytostatic effect on certain human tumours. The effect of this drug in reticulosarcoma is of great interest, for up till now a similar percentage of objective regressions was obtained only with cyclophosphamide (Carbone and Spurr, 1968; Hyman and Cassileth, 1966) and vincristine (Carbone and Spurr, 1968; Desai et al., 1970). In view of these results it is tempting to propose the use of this drug not only for the primary treatment of reticulosarcomas in stages III and IV, but as a chemotherapy complementary to radiotherapy for stages I and II. With this aim in mind, some physicians in this group are giving epipodophyllotoxin intermittently (150 mg every second week) over long periods.

The action of epipodophyllotoxin in Hodgkin's disease and in lymphosarcomas is equally notable. However, in these diseases the drug is of less importance than in the reticulosarcomas, for each of these diseases is already known to be sensitive to several drugs.
The single apparently complete regression and the three partial regressions of bladder cancers are most encouraging, and this will be examined further by complementary trials by the Urogenital Cancer Co-operative Group of E.O.R.T.C.

Finally, we draw attention to the resolution of pleural effusions in five patients which were apparently complete and fairly long lasting (four to five months); such results are only exceptionally achieved with other forms of systemic chemotherapy. We are now studying the possible mesothelial tropism of this drug.

Clearly it is the toxic action on the bone marrow that is the main factor limiting the use of this drug. This might be overcome by using the drug in combination with another agent which shows some action against the same types of tumours that are affected by epipodophyllotoxin, but which is not toxic to the bone marrow; bleomycin has these characteristics (E.O.R.T.C., 1970, 1972).

Requests for reprints should be addressed to the Institut de Cancérologie et d'Immunogénétique, Hôpital Paul-Brousse, 14 Avenue Paul Vaillant Couturier, 94 Villejuif, France.

VM 26 was supplied by Sandoz Laboratories.

\section{References}

Carbone, P. P., and Spurr, C. (1968). Cancer Research, 28, 811. Desai, D. V., Ezdinli, E. Z., and Stutzman, L. (1970). Cancer (Philadelphia), 26, 352 .

E.O.R.T.C., Clinical Screening Co-operative Group (1970). British Medical Fournal, 2, 643.

E.O.R.T.C., Co-operative Group for Leukaemia and Reticulocytoses (1972). British Medical fournal, 1, 285.

Hyman, G. A., and Cassileth, P. A. (1966). Cancer (Philadelphia), 19, 1386. Stähelin, H. (1970). European fournal of Cancer, 6, 211.

\section{MEDICAL MEMORANDA}

\section{Gold-induced Thrombocytopenia and Response to Dimercaprol}

\author{
J. M. ENGLAND, D. S. SMITH
}

British Medical fournal, 1972, 2, 748-749

Several types of thrombocytopenia may occur during gold therapy. Commonly the patient's platelet count falls, the gold therapy is temporarily discontinued, and a rapid recovery ensues. On other occasions a more profound and persistent thrombocytopenia occurs (Meyler and Herxheimer, 1968), and these cases may have either an aplastic marrow or, more unusually, changes suggestive of toxicity to the megakaryocytes.

We report here the case of a patient who recovered from a severe and persistent thrombocytopenia. In the literature are only a few examples of successful treatment of this condition (Lockie et al., 1947; Honkapohja, 1949; Kroese, 1949; Thompson et al., 1954; Saphir and Ney, 1966; Stavem et al., 1968).

\footnotetext{
Departments of Haematology and Rheumatology, Northwick Park Hospital and Clinical Research Centre, Harrow, Middlesex

J. M. ENGLAND, M.B., B.S., B.sC., M.R.C. Research Fellow

D. S. SMITH, M.B., CH.B., M.R.C.P., Consultant Physician in Rheumatology and Rehabilitation
}

\section{Case Report}

A 56-year-old woman with a two-year history of rheumatoid arthritis gained little relief on salicylate therapy and was given a course of sodium aurothiomalate injections. The first injection of $5 \mathrm{mg}$ was given without any side effects being noted (this was 34 days before Day 0 on the Chart), and further injections totalling $140 \mathrm{mg}$ were given over the ensuing 28 days. During this period her platelet count remained at around $300,000 / \mathrm{mm}^{3}$, with a normal haemoglobin and white blood count. No eosinophilia was seen.

Seven days after her last injection of gold she presented with widespread purpura and a subconjuctival haemorrhage in the right eye. Pulse $76 / \mathrm{min}$, B.P. $125 / 85 \mathrm{~mm}$ Hg. There was no splenomegaly or lymphadenopathy, and no skin lesions other than purpura were found Some blood was present in the urine, but tests for occult blood in the stool were negative.

The haemoglobin was $12.9 \mathrm{~g} / 100 \mathrm{ml}$, white blood count was $7,900 /$ $\mathrm{mm}^{3}$ platelets were $<5,000 / \mathrm{mm}^{3}$, three tests for $\mathrm{L}$.E. cell reaction were negative, and prothrombin and kaolin-cephalin times, urea and electrolytes, liver function tests, and chest $x$-ray appearances were all normal. No platelet antibodies were detected when looking for platelet agglutinins or when testing for incomplete antibodies by the direct antiglobulin consumption test or the complement fixation test.

The thrombocytopenia was initially treated with infusions of either platelet concentrate (15 units/day) or platelet-rich plasma (10 units/ day with frusemide) and no further injections of gold were given.

After seven days of platelet therapy there had been only a transient rise in the platelet count to $23,000 / \mathrm{mm}^{3}$ after the administration of platelet-rich plasma. At this stage the bone marrow showed many young megakaryocytes with little evidence of platelet budding. (The Chart shows the platelet count each morning. The platelet tranfusions were given in the afternoon.) At other times the platelet 